\title{
PENINGKATAN MOTIVASI KONSUMSI SAYUR DAN BUAH MELALUI COGNITIVE BEHAVIOUR THERAPY (CBT)
}

\author{
ETIKA PURNAMA SARI \\ AKADEMI KEPERAWATAN ADI HUSADA SURABAYA \\ etika.purnamasari@yahoo.com
}

\begin{abstract}
Many children didn't like to consume vegetables and fruit, they consumed it in value standard below from WHO. The aim from this study explained the increasing motivation within consume vegetables and fruits through Cognitive Behaviour Therapy (CBT). The study design was quasy experiment with prepost control group design. The variables studied were motivation within consume vegetables and fruits. The samples obtained were 27 respondents for intervention group and 28 respondents for control group using purposive sampling. Collecting data includes demographic data and motivation data with questionnaire. Based on Mann Whitney U Test, $p$ value for pretest between intervention and control group was 0,495 with $\alpha=0,05$ it means that there wasn't different in motivation consume vegetables and fruit, but for posttest $p$ value was 0,029 it means that there was different in motivation. Based on mean value, there was increasing value for intervention group from 29,30 to 31,91 it means that CBT could increasing motivation to concume vegetables and fruits in children. The increasing motivation could happen because CBT changes the irrational thinking or negative thinking about vegetables and fruit to rational thinking or positive thinking. CBT could be an alternative method to motivate children to consume vegetables and fruits.
\end{abstract}

\begin{abstract}
ABSTRAK
Banyak anak-anak tidak suka mengkonsumsi sayur dan buah sehingga menunjukkan angka dibawah standar WHO. Tujuan dari penelitian ini adalah menjelaskan tentang peningkatan motivasi konsumsi sayur dan buah melalui Cognitive Behaviour Therapy (CBT). Desain penelitian yang digunakan adalah quasy experiment dengan kelompok kontrol pre-post. Variabel yang diteliti adalah motivasi dalam mengkonsumsi sayur dan buah. Sampel yang digunakan terdapat 27 responden untuk kelompok perlakuan dan 28 reponden untuk kelompok kontrol dengan menggunakan purposive sampling. Pengambilan data menggunakan kuesioner demografi dan motivasi. Berdasarkan hasil tes Mann Whitney $U$ dengan signifikansi $\mathrm{p}=0,05$ didapatkan nilai $\mathrm{p}=0,495$ pada pretest antara kelompok kontrol dan perlakuan, sehingga tidak terdapat perbedaan motivasi sedangkan pada hasil posttest kelompok kontrol dan perlakuan menunjukkan $\mathrm{p}=0,029$ sehingga terdapat perbedaan dan dan terdapat peningkatan mean value pada kelompok kontrol dari 29,30 menjadi 31,91. Hal tersebut membuktikan bahwa CBT mempengaruhi motivasi anak-anak dalam mengkonsumsi sayur dan buah. Peningkatan motivasi terjadi karena CBT dapat mengubah pemikiran irasional dan negatif terhadap sayur dan buah menjadi lebih rasional dan positif. CBT dapat digunakan sebagai metode alternatif dalam meningkatkan motivasi anak untuk mengkonsumsi sayur dan buah.
\end{abstract}

Keywords: Cognitive Behavior Therapy, Vegetables and Fruits, Motivation

\section{PENDAHULUAN}

Saat ini masih banyak anak yang belum menyukai dan mengkonsumsi sayuran dan buah 1, serta belum memenuhi standar angka konsumsi sayur dan buah yang ditetapkan oleh WHO dan FAO. $^{7}$ Setiap individu direkomendasikan untuk mengkonsumsi setiap kelompok makanan, tetapi sebagian besar individu hanya mengkonsumsi kelompok makanan tertentu dan melewatkan atau sedikit mengkonsumsi buah dan sayuran. Anak usia 712 tahun merupakan anak usia sekolah dasar dimana mereka memiliki karakteristik mulai ingin mencoba mengembangkan kemandirian dan menentukan keinginannya sendiri. Mereka juga sudah pandai menentukan makanan yang mereka sukai karena sudah mengenal lingkungan, biasanya mereka lebih menyukai makanan instan atau fast food (makanan siap saji) daripada mengkonsumsi sayur dan buah. ${ }^{5}$ 
Menurut riset yang dilakukan Departemen Kesehatan pada tahun 2007, hanya terdapat 10 persen orang Indonesia dengan usia 10 tahun ke atas yang asupan buah sehari-harinya mencukupi kebutuhan. ${ }^{6}$ Data yang didapat Riset Kesehatan Dasar (Riskesdas) tahun 2013 menyatakan bahwa kurang lebih 93\% anak-anak di Indonesia tidak cukup makan sayur-sayuran dan buahbuahan. ${ }^{2}$ Berdasarkan hasil survei awal yang dilakukan di SDN Bulak Rukem no. 258 pada siswa kelas $\mathrm{V}$ sebanyak 38 orang dengan menggunakan kuesioner didapatkan dalam hal konsumsi sayur dan buah yang mengatakan makan sayur dan buah rutin setiap hari hanya $15 \%$ (6 orang) dan $85 \%$ (32 orang) mengatakan makan sayur dan buah tidak setiap hari, 52\% (20 orang) mengatakan pernah mengalami susah buang air besar (BAB) atau konstipasi dan $48 \%$ (18 orang) mengatakan tidak, 56\% (21 orang) mengatakan pola $\mathrm{BAB}$ tidak teratur dan $44 \%$ (17 orang) teratur, $60 \%$ (23 orang) mengatakan sering mengalami sakit flu dan sisanya $40 \%$ mengatakan jarang.

Dalam mengakses dan memilih makanan pada anak dipengaruhi oleh beberapa factor, salah satunya factor lingkungan, baik itu lingkungan rumah maupun di luar rumah. ${ }^{4}$ Rendahnya konsumsi buah dan sayuran dalam jangka panjang dapat meningkatkan terjadinya penyakit kronis tersebut, dan juga dapat menyebabkan kekurangan vitamin (A, C, dan E), kekurangan mineral (kalsium dan zat besi), dan konstipasi (sulit buang air besar). ${ }^{5}$

Cognitive Behavioral Therapy (CBT), merupakan suatu terapi yang efektif untuk berbagai masalah seperti masalah makan, perilaku kekerasan, kecemasan dan panik, permasalahan anak dan remaja, sindrom kelelahan kronis, nyeri kronis, depresi, kecanduan obat atau alkohol, masalah tidur, kesehatan umum, perubahan suasana hati, obsesif kompulsif, fobia, pasca traumatic stress disorder, masalah seksual dan hubungan sosial. ${ }^{3}$ Berdasarkan hal tersebut diatas, peneliti tertarik untuk meneliti peningkatan motivasi konsumsi sayur dan buah melalui Cognitive Behavioral Therapy (CBT) pada anak usia sekolah dasar.

\section{METODE PENELITIAN}

Rancangan penelitian yang akan digunakan adalah quasy experiment (eksperimen semu) dengan "pre post test control group design" yaitu memberikan suatu perlakuan kelompok dan adanya kelompok kontrol. Waktu Penelitian dilakukan pada bulan April 2015 di SDN Bulak Rukem Timur I no. 258 Surabaya. Perekrutan responden dengan metode purposive sampling dengan menetapkan kriteria inklusi dan ekslusi. Kriteria inklusi meliputi: siswa yang tidak makan sayur dan atau buah setiap hari, mengisi kuesioner dengan lengkap dan bersedia menjadi responden. Kriteria ekslusi meliputi: siswa yang tidak hadir saat dilakukan penelitian dan mengundurkan diri selama dilakukan penelitian.

Jumlah sampel yang didapat adalah 27 orang pada kelompok perlakuan dan 28 orang pada kelompok kontrol. Dalam penelitian ini variable diukur dengan menggunakan alat ukur kuesioner motivasi konsumsi sayur dan buah sebanyak 12 pertanyaan.

Perlakuan yang diberikan berupa Cognitive Behavior Therapy (CBT) sebanyak 6 sesi dalam 3x tatap muka. Sedangkan kelompok control diberikan terapi standar yaitu penyuluhan.

\section{HASIL}

Tabel 1 Data Demografi

\begin{tabular}{|c|c|c|c|c|c|}
\hline \multirow{3}{*}{ No. } & \multirow{3}{*}{ Karakteristik } & \multicolumn{2}{|c|}{$\begin{array}{l}\text { Kelompok } \\
\text { perlakuan }\end{array}$} & \multicolumn{2}{|c|}{$\begin{array}{l}\text { Kelompok } \\
\text { kontrol }\end{array}$} \\
\hline & & Total & & Total & \\
\hline & & $\mathrm{f}$ & $\%$ & $\mathrm{f}$ & $\%$ \\
\hline \multirow[t]{4}{*}{1} & $\begin{array}{l}\text { Umur } \\
\text { (tahun) }\end{array}$ & 11 & $\Delta 1$ & 12 & 16 \\
\hline & 11 & & & & \\
\hline & 12 & 16 & 59 & 14 & 50 \\
\hline & 13 & 0 & & 1 & 4 \\
\hline 2 & $\begin{array}{l}\text { Jenis } \\
\text { Kelamin }\end{array}$ & & & & \\
\hline
\end{tabular}




\begin{tabular}{llllll}
\hline & $\mathrm{L}$ & 16 & 59 & 18 & 64 \\
\cline { 2 - 6 } & $\mathrm{P}$ & 11 & 41 & 10 & 36 \\
\hline 3 & Suku & & & & \\
\cline { 2 - 6 } & Jawa & 26 & 96 & 26 & $\frac{93}{7}$ \\
\cline { 2 - 5 } & Madura & 1 & 4 & 2 & \\
\hline
\end{tabular}

Berdasarkan tabel 1 pada kelompok perlakuan dapat dilihat bahwa sebagian besar responden berusia 12 tahun (59\%), sebagian besar berjenis kelamin laki-laki (59\%) dan mayoritas suku Jawa (96\%).

Berdasarkan tabel 1 pada kelompok kontrol dapat dilihat bahwa sebagian besar responden berusia 12 tahun $(50 \%)$, sebagian besar berjenis kelamin laki-laki (64\%) dan mayoritas suku Jawa (93\%).

Tabel 2. Motivasi Konsumsi Sayur dan Buah

\begin{tabular}{llll}
\hline \multirow{2}{*}{ No. } & Motivasi & Sig. 2 tailed \\
& Pretest & Posttest \\
\hline 1. & $\begin{array}{l}\text { Kelompok } \\
\text { kontrol dan } \\
\text { perlakuan }\end{array}$ & 0,495 & 0,029 \\
\end{tabular}

Berdasarkan table 2 diketahui nilai sig. 2 tailed Mann Whitney Test pada saat pretest adalah 0,495 dengan nilai $\alpha=0,05$ artinya tidak terdapat perbedaan motivasi antar kelompok perlakuan dan kelompok kontrol, sedangkan pada posttest nilai sig. 2 tailed 0,029 yang berarti terdapat perbedaan antara kelompok perlakuan dan kelompok kontrol.

Tabel 3 Motivasi Konsumsi Sayur dan Buah

\begin{tabular}{llll}
\hline \multirow{2}{*}{ No. } & Motivasi & Mean & \\
& & Pretest & Posttest \\
\hline 1. & $\begin{array}{l}\text { Kelompok } \\
\text { perlakuan }\end{array}$ & 29,30 & 31,91 \\
& & \\
\end{tabular}

\begin{tabular}{lll}
\hline 2. & Kelompok \\
kontrol & 26,75 & 24,23 \\
&
\end{tabular}

Berdasarkan tabel 3 didapatkan nilai mean yang meningkat pada kelompok perlakuan yaitu dari 29,30 menjadi 31,91, hal ini menunjukkan bahwa CBT berpengaruh terhadap motivasi dalam konsumsi sayur dan buah.

\section{PEMBAHASAN}

Berdasarkan hasil tabel 3 didapatkan nilai mean yang meningkat pada kelompok perlakuan yaitu dari 29,30 menjadi 31,91. Terdapat peningkatan sebesar 2,61 pada kelompok perlakuan yang diberikan CBT, sedangkan pada kelompok control tidak didapatkan peningkatan motivasi dilihat dari nilai mean pada pretest dan posttest.

Cognitive Behavior Therapy merupakan gabungan dua macam teknik psikoterapi yang efektif yaitu terapi kognitif dan terapi perilaku. Terapi kognitif dalam Cognitive Behavior Therapy membantu klien untuk mengubah pikiran, perasaannya, sedangkan terapi perilaku mengubah perilakunya. ${ }^{4}$ Cognitive Behavioral Therapy (CBT) dapat mengubah motivasi, sikap dan perilaku seseorang dengan berfokus pada pikiran, keyakinan dan sikap yang kita pegang (proses kognitif) dan bagaimana hal ini berhubungan dengan cara kita berperilaku, sebagai cara untuk mengatasi masalah emosional. ${ }^{1}$

Oleh karena hal tersebut motivasi pada kelompok perlakuan dapat meningkat, melalui CBT klien atau responden yang memiliki keyakinan atau pandangan yang negatif atau irasional tentang konsumsi sayur dan buah akan diubah menjadi keyakinan atau pandangan yang positif sehingga motivasi responden pada kelompok perlakuan meningkat, namun pada kelompok control tidak terjadi hal yang sama.

\section{SIMPULAN}

Berdasarkan keseluruhan hasil dan pembahasan dalam penelitian ini maka dapat disimpulkan, bahwa terdapat peningkatan motivasi konsumsi sayur dan buah melalui Cognitive Behavior Therapy (CBT). 


\section{SARAN}

CBT dapat digunakan sebagai metode alternatif dalam meningkataktan motivasi anak dalam mengkonsumsi sayur dan buah.

\section{KEPUSTAKAAN}

1. Beck, Judith S. 2011. Cognitive Behavior Therapy: Basic and Beyond. $2^{\text {nd }}$ ed. New York: The Guilford Press.

2. Departemen Kesehatan RI. 2014. Laporan Hasil Riset Kesehatan Dasar (Riskesdas) Tahun 2013. Jakarta: Badan Penelitian dan Pengembangan Kesehatan Depkes RI.

3. Manuntung, Alfeus. 2014. Pengaruh Cognitive Behavioral Therapy (CBT) Terhadap Self Efficay dan Self Care Behavior pada Pasien Hipertensi. Tesis Magister Keperawatan. Universitas Airlangga. Surabaya.
4. Nevid, J. S. 2005. Psikologi Abnormal. Jakarta: Erlangga.

5. Ratnasari, Dewi Kristina. 2012. Gambaran Kebiasaan Konsumsi Mie Isntan Pada Anak Usia 7-12 Tahun. Skripsi Ilmu Gizi. UNDIP. Semarang.

6. Sofia, Maya dan Paramitha, Tasya. 2013. Asupan buah dan sayur masyarakat Indonesia masih rendah. www.viva.co.id. Diakses tanggal 2 Februari 2015. Jam 09.30 WIB.

7. Walker. 2005. Eat, Play and be Healthy. McGraw Hill. 